\title{
Contenido mitológico en El Pantheón real por el alma de Doña María Amalia de Sajonia \\ Mythological content in the Pantheón real por el alma de Doña María Amalia de Sajonia
}

\section{Maricela Cerdas Fallas*}

\section{RESUMEN}

En este artículo se examinará la presencia de divinidades procedentes de la mitología grecolatina en la obra Pantheón real por el alma de Doña María Amalia de Sajonia, escrita por Juan Antonio Dighero y publicada en 1763. Este texto se inscribe dentro del género denominado relaciones de sucesos, específicamente del tipo de relaciones de fiestas. En el artículo se tratan aspectos como características distintivas de algunas divinidades y su relación con la persona de la reina y con sus exequias.

Palabras clave: Relaciones de fiestas, mitología grecolatina, María Amalia de Sajonia, emblemática, exequias reales.

\begin{abstract}
This article deals with the presence of gods from Greek and Roman Mythology in the Pantheón real por el alma de Doña María Amalia de Sajonia, written by Juan Antonio Dighero and published in 1763. This text is an example of Baroque festivals. Elements like distinctive characteristics of some of the gods and their connection to the queen and her funerals are approached in the article.
\end{abstract} Key Words: Baroque festivals, Graeco-Latin mythology, Maria Amalia of Saxony, emblematica, royal funerals.

\section{Las exequias de reinas en colonias españolas}

"Las exequias u honras fúnebres por las personas reales constituyen una de las partes más significativas del protocolo ceremonial funerario de la monarquía hispana durante el Antiguo Régimen" (Allo y Esteban, 2004, p. 39). Asimismo, tenían carácter público y obligatorio, por lo que debían ser celebradas por todos los súbditos (p. 40) y constituían una ocasión para las provincias americanas de mostrar su lealtad para con el monarca. Por esta razón, en las ciudades bajo la jurisdicción administrativa de la Corona española, se llevaban a cabo estas ceremonias de manera solemne y de acuerdo con las posibilidades económicas de cada una. Según los mismos autores:

\footnotetext{
* Universidad de Costa Rica. Docente, Escuela de Filología, Lingüística y Literatura. Costa Rica. Correo electrónico: tortuka@gmail.com Recepción: 12/09/2019. Aceptación: 03/02/2020.
} 
Las contribuciones artísticas realizadas para (...) los aparatos fúnebres se centraron, básicamente, en la construcción de un grandioso túmulo arquitectónico y en la realización de un importante conjunto de imágenes simbólicas que, en forma de esculturas y pinturas, sirvieron tanto de adorno del túmulo como del resto del espacio celebrativo (p. 41).

\section{El Pantheón real por el alma de Doña María Amalia de Sajonia}

La obra Pantheón real por el alma de Doña María Amalia de Sajonia, publicada en 1763, es la descripción de las exequias que, por mandato real, se llevaron a cabo en la ciudad de Santiago de los Caballeros de Guatemala con motivo de la muerte de la reina María Amalia de Sajonia, esposa del rey Carlos III de España, reina consorte de Nápoles y Sicilia (1737-1759) y de España (1759-1760). Nació en Dresde en 1724. Dos años después de su llegada a España murió de una afección pulmonar en 1760.

En palabras de Sánchez (2019, p. 1), dentro de las monarquías modernas y en el caso particular de la española, la reina consorte constituía un espejo de virtudes para todas las mujeres y era uno de los referentes femeninos por excelencia, junto con la matrona romana y la Virgen María. Según este autor, en los virreinatos americanos, debido a las difíciles condiciones para viajar que predominaban en la época, "la presencia de esta figura real femenina se sentía principalmente con ocasión de su muerte y los rituales de enterramiento que la acompañaban" (p. 4).

El texto Pantheón real por el alma de Doña María Amalia de Sajonia forma parte de las obras denominadas libros de exequias, los cuales son un resumen oficial de la ceremonia una vez finalizada (Allo y Esteban, 2004, p. 48). A su vez, se ubica dentro del género discursivo de las relaciones de sucesos, específicamente del subgénero de las relaciones de fiestas. Como indica Sánchez (2016, p. 118), las relaciones de sucesos tienen en primera instancia una finalidad informativa, a la que se le pueden agregar otras como mostrar fidelidad a la corona o hacer propaganda de los poderes civil y eclesiástico. 
El autor del Pantheón real fue Juan Antonio Dighero, doctor en Derecho y canónigo de la Iglesia Metropolitana de Santiago de los Caballeros de Guatemala. Dighero nació en 1716 en Santiago, dentro de una familia que gozaba de cierto poder en la ciudad, y murió en 1792 en Nueva Guatemala. En 1742 obtuvo el Bachillerato en Leyes y Cánones en la Real y Pontificia Universidad de San Carlos. Además, fue Alcalde Segundo de la Ciudad de Santiago en 1728. Se desempeñó como Chantre del Cabildo Eclesiástico y profesor de Leyes en la Universidad de San Carlos entre 1768 y 1788, año en que solicitó su jubilación. Asimismo, fungió en varias ocasiones como rector de la Universidad de San Carlos, la última en $1790 .{ }^{1}$ Dighero fue uno de los opositores al traslado de la capital de la Capitanía General de Guatemala cuando un terremoto destruyó buena parte de la ciudad en 1773 (Álvarez, 2016, p. 158). Apunta el propio autor que, distraído por otras ocupaciones, tardó algún tiempo en componer su obra y advierte que es posible que los doctos lectores noten la necesidad de una labor limae más rigurosa (Dighero, 1763, p. 25). ${ }^{2}$

Luego de las licencias necesarias para su impresión (que dan constancia de que el libro no se opone a la fe católica ni a las buenas costumbres), la obra inicia con los versos 279 al 283 del "«Suplemento a la Eneida» o «libro XIII de la Eneida», escrito en latín por el humanista italiano Maffeo Vegio, (...) libro épico que, a lo largo de 630 hexámetros, continúa el argumento de la epopeya de Virgilio" (Cristóbal, 1993, p. 189). Estos versos contienen un lamento por la desgracia que constituye la muerte para los seres humanos de cualquier condición.

Seguidamente, el autor narra cómo llegó la noticia de la muerte de la reina a la ciudad, en abril de 1761, y cómo los habitantes se vieron embargados de gran dolor por este suceso. A continuación, se explica que la organización de las exequias en honor a María Amalia estuvo a cargo del Capitán General de la provincia y que se llevaron a cabo en la Iglesia Metropolitana. Allí se erigió una pira funeraria, cuya descripción emprenderá el autor por si "aquí pudiera servir de animar un tanto la idea de la estampa, que apenas ministra confussas señas de su original; pero passe assí en obsequio de la brevedad, y sea essa muerta

\footnotetext{
${ }^{1}$ Información tomada de https://www.afehc-historia-centroamericana.org/index_action_fi_aff_id_2655.html

${ }^{2}$ Debido a que el Pantheón Real no cuenta con páginas numeradas, la numeración utilizada en el presente artículo toma como página 1 la portada de la obra.
} 
lámina geroglyphico expresso de una Magestad difunta” (Dighero, 1763, p. 25). Señala Dighero que el túmulo contaba con cuatro frentes, en los cuales se hallaban las siguientes inscripciones:

a. Un epitafio en latín, titulado Aeternitati.

b. Un poema dedicado a María Amalia, igualmente en latín, con el título Maria Amalia Saxonum Princeps.

c. Un epitafio en español.

d. Dos elegías, la primera en latín y la segunda en español.

Finalmente, se llega a la descripción de las imágenes que adornaban los alrededores de la pira dentro de la iglesia. Dighero (1963) llama a estas imágenes symbolos, que "para explicar la extensión, y grandeza de un tan reciente dolor, se traxeron por la Mythologia desde los más extraños países de la Antigüedad” (p. 25). En palabras de Cristóbal (2000), "los mitos clásicos han sido, en efecto, desde la misma civilización que les dio crédito y vida, fuente inagotable de inspiración para las letras" (p. 30), en un inicio dentro de la cultura griega; de ahí pasaron a las literaturas europeas (entre ellas, la española) y posteriormente a la hispanoamericana. Así, "por el prestigio de la cultura clásica, los mitos transmitidos en la literatura de Grecia y Roma se han convertido (...) en mitos de la literatura occidental" (p. 31) Debido a ello, el conocimiento de la mitología grecolatina es instrumento esencial en la interpretación literaria. En el caso específico de la producción artística en territorio americano, como indica Barchino (2008):

La instalación temprana de una dinámica sociedad virreinal provocó una incorporación a lo americano de la tradición cultural greco-latina y judeocristiana y dio lugar a la incorporación de la mitología antigua y clásica a las obras artísticas y literarias de la colonia (p. 90).

Las imágenes mitológicas utilizadas hacían alusión a la vida de la difunta reina y al dolor que su muerte causó y se distribuyeron espacialmente en cuatro estancias. Termina la obra con una reseña del funeral propiamente dicho: se indica que la fecha fue el 27 de setiembre, se enlista a los personajes de altos cargos de la ciudad que se hicieron presentes, se mencionan las campanadas y cañonazos que precedieron a los oficios religiosos y se concluye con la ceremonia en la Iglesia Metropolitana. 
Las imágenes referidas, que colgaban alrededor de la pira funeraria, consistían en emblemas o jeroglíficos. El género emblemático, de carácter literario-artístico, "nació de la mano del ilustre jurista milanés Andrés Alciato, cuyo libro de poemas titulado Emblemata apareció publicado por Heinrich Steyner en Augsburgo en el año 1531” (Ureña, 2001, p. 437). En palabras de Skinfill (2002), estas representaciones icónico-literarias tuvieron relevancia tanto en la esfera pública como en la privada de la vida en Nueva España, en actividades como nacimientos y bodas reales, funerales y procesiones triunfales:

Gracias a toda la gama de manifestaciones emblemáticas, este lenguaje simbólico se convirtió en un saber ampliamente difundido y en una forma eficaz de educar y adoctrinar a todos los grupos sociales novohispanos tanto para fortalecer su fe cristiana, como para reafirmar sus lazos de lealtad con la monarquía (p. 45).

Según Henkel y Schöne (1967, p. XII), el emblema consta de una estructura tripartita con los siguientes elementos:

a. Una pictura o imagen, conocida además como icon, imago o symbolon, que puede mostrar diversos elementos: plantas, animales, máquinas, hechos o asuntos de la vida humana. También puede representar una escena o figura bíblica, histórica o mitológica.

b. Un título, también llamado lemma, inscriptio o motto, que puede estar en latín, en griego o en lengua vernácula. A menudo el lemma consiste en sentencias o citas, ya sea bíblicas o de autores de la Antigüedad.

c. Un texto explicativo de la pictura, que puede ser bien una composición poética (como un epigrama) o un texto en prosa.

Sin embargo, es importante acotar que, en el Pantheón real de Dighero, las láminas que adornaban la pira no fueron reproducidas y en su lugar cada imagen se transmite a través de la descripción o recreación que de ella hace el autor. Entonces, se está ante una sucesión de écfrasis.

Como se mencionó, los jeroglíficos estaban distribuidos en cuatro estancias de la siguiente manera, para un total de 40 imágenes: 
a. Estancia primera: Dioses celestes y terrestres (16 jeroglíficos; el primero no es una divinidad, sino que corresponde a la Idea de la Obra).

b. Estancia segunda: Dioses terrestres y marinos (16 jeroglíficos).

c. Estancia tercera: Dioses infernales (4 jeroglíficos).

d. Estancia cuarta: Dioses honorarios (4 jeroglíficos).

Cada estancia presenta una introducción relativa a las divinidades que se incluyen y su relación con la reina. A su vez, cada emblema descrito posee los siguientes elementos:

a. Título del emblema. En la primera estancia, se incluye en el título el nombre de la divinidad correspondiente y un subtítulo en el cual se establece la razón de la presencia de la divinidad escogida (la virtud que representa). En las restantes estancias el título consiste únicamente en el nombre de la divinidad.

b. Écfrasis de la pictura original, llamada symbolo por el autor, y al final de esta el lemma en lengua latina.

c. Una composición poética explicativa de la relación de la divinidad representada con la reina y su muerte; puede tratarse de un epigrama, un soneto, una octava o una décima.

El primer jeroglífico, con el título Idea de la Obra, explica el porqué de la escogencia del Pantheón como motivo metafórico central para las exequias de la reina. En la Antigua Roma, el Panteón era el templo consagrado a todos los dioses, construido por el emperador Adriano. Posteriormente fue convertido en iglesia cristiana por el papa Bonifacio IV en 609. Indica Dighero (1763) que Pantheón es asimismo el nombre con el que se designaba el sepulcro de reyes y príncipes, debido a su semejanza estructural (bóveda redonda) (p. 27). El lemma de este primer emblema es De morte ad vitam. De esta manera, el panteón como sepulcro es, en primera instancia, un digno lugar de reposo para la realeza y, a la vez, lo que antes estaba muerto, las antiguas divinidades paganas, adquieren nueva vida: el antiguo templo es ahora una iglesia cristiana, las antiguas deidades son ahora símbolos de virtud cristiana y, tal como el panteón romano reunía a todos los dioses y reflejaba la grandeza de esa civilización, ahora el Pantheón real los vuelve a reunir con un nuevo significado: ilustrar las numerosas virtudes de la difunta reina María Amalia. 


\section{Contenido mitológico de la obra}

Los personajes divinos que se encuentran en la obra de Dighero son los siguientes, distribuidos según estancias:

a. Estancia primera: Comprende a los dioses celestes y terrestres. Cada uno se acompaña con una mención de la virtud o sentimiento que representa.

II. El Rey en su dolor: Júpiter.

III. Memoria del dolor del reino: Juno.

VI: La virtud viva de la reina difunta: Aurora.

V. Su genio: particular motivo a la pena: Apolo.

VI. Su ingenio: nueva razón de su temprana muerte: Mercurio.

VII. Su piedad y devoción: Vesta.

VIII. Su labor y ejercicio de manos: Vulcano.

IX. Su medida y compostura: Venus.

X. Su moderación en el fausto: Minerva.

XI. Su dichosa fecundidad: Cibele.

XII. Su doctrina y educación: Eolo.

XIII. Su austeridad y mortificación: Marte.

XIV. Su recato y silencio en la virtud: Saturno.

XV. Su liberalidad con los pobres: Jano.

XVI. Su bondad y justicia final: Astrea.

b. Estancia segunda: Dioses terrestres y marinos. Aquí están presentes Pan, Ceres, Pales, Feronia, Aristeo, Diana, Flora, Pomona, Sileno, Momo, Océano, Thetys, Ino, Glauco, Tritón y Neptuno.

c. Estancia tercera: Dioses infernales. En ella se ubican las Parcas, Charonte, la Noche y el 
Sueño.

d. Estancia cuarta: Dioses honorarios. Aquí se encuentran el Honor, la Fortuna, la Fama y el Silencio.

Las 39 divinidades incluidas en el Pantheón real tienen distintas procedencias. La mayoría de ellas son las griegas (posteriormente asimiladas a las romanas), las cuales se mencionan en la Teogonía de Hesíodo, poeta épico griego del siglo VIII a. C. Este autor es considerado, junto con Homero, padre y precursor de la mitología griega y es, por consiguiente, un referente mitológico de la Antigüedad. La Tabla 1 muestra la distribución de los dioses mencionados en el Pantheón real de acuerdo con la organización de la obra de Hesíodo. Cabe aclarar que Dighero utiliza siempre los nombres romanos; en la Tabla 1 aparece tanto el nombre griego como el romano.

Tabla 1

Dioses del Pantheón real presentes en la Teogonía

\section{Divinidades del Pantheón real según la Teogonía}

\begin{tabular}{ll} 
Primera generación de dioses & Nyx / Noche: hija de Caos (Teog. 123). \\
Segunda generación de dioses & Crono / Saturno: hijo de Urano y Gea (Teog. \\
& 133). \\
& Momo, Hipnos / Sueño: hijos de Nyx (Teog. \\
& $212)$. \\
& Océano, Thetys: hijos de Gea y Urano (Teog. \\
& $133)$. \\
& Eos / Aurora: hija de Hiperión y Tía (Teog. \\
& 372). \\
& Hijos de Crono y Rea: \\
& Zeus / Júpiter, Hera / Juno, Deméter / Ceres, \\
& Poseidón / Neptuno, Hestia / Vesta (Teog. 123). \\
\hline Tercera generación de dioses & Hijos de Júpiter: \\
& Apolo, Ártemis / Diana (Teog. 919), Ares / \\
& Marte (Teog. 922), Atenea / Minerva (Teog. \\
Cuarta generación de dioses & 924), Hefesto / Vulcano (Teog. 928), Hermes / \\
& Mercurio (Teog. 937), Moiras / Parcas (Teog. \\
& 903). \\
& Hijo de Poseidón: \\
Tritón (Teog. 935). \\
Ino: hija de Cadmo y Harmonía (Teog. 976). \\
\hline Afrodita / Venus (Teog. 188-199). \\
\hline Otros
\end{tabular}

Fuente: Elaboración propia. 
Afrodita /Venus no se cuenta en ninguna generación, puesto que nació de la espuma del mar al caer en este los genitales de Urano.

Otras divinidades grecorromanas del Pantheón no son mencionadas en Hesíodo, pero sí en las Metamorfosis, poema del romano Ovidio. Esta obra abarca 250 episodios de la tradición mitológica griega y romana y constituye "la más acabada y sistemática visión de la mitología que nos ha transmitido la Antigüedad clásica" (Fernández Corte y Cantó Llorca, 2008; cit. en Ovidio, 2008, p. 115). Estas divinidades son Eolo (Met. XIV, v. 223), Astrea (Met. I, v. 149), Sileno (Met. XI, v. 90), Glauco (Met. XIII, v. 906) y Caronte, al cual se hace alusión solo como el barquero que traslada las almas a través del río de los muertos hasta el inframundo (Met. X, v. 72).

En la obra aparecen también divinidades solamente romanas: Jano, Pomona, Flora, Honos y Fortuna, aunque esta última se relaciona con la griega Tyche. Finalmente, se incluyen dos deidades de otras culturas: Cibeles, de Frigia (Asia Menor) y Harpócrates (Silencio), originalmente egipcio, pero luego adoptado en Grecia.

A continuación, se analizan algunos ejemplos de divinidades utilizadas en emblemas provenientes de cada una de las cuatro estancias, como modelo para ilustrar su función en las exequias de la reina María Amalia.

\subsection{Primera estancia. Dioses celestes y terrestres}

Dighero (1763) explica en su introducción que los paganos creían "torpemente" en sus divinidades debido a que vislumbraban en ellas "alguna sobresaliente especie de virtud" (p. 26). Desde ese punto de vista, no está fuera de lugar para cristianos devotos utilizar símbolos paganos para representar virtudes cristianas. Por consiguiente, el autor menciona que en la primera estancia se colocaron las deidades más sobresalientes, con el propósito de que representaran las principales virtudes y de esta manera ilustraran las que adornaban a la reina María Amalia. Advierte el autor que al principio se presentan las divinidades que hacen alusión al dolor, por ser este el tema que más cabida tiene dentro de las exequias (p. 27). 


\subsubsection{El rey en su dolor: Júpiter (II)}

Júpiter es un dios romano asimilado al griego Zeus. Es el dios principal del panteón romano y “aquel de quien emana toda autoridad" (Grimal, 1981, p. 299). Además, según este mismo autor, esta concepción de Zeus como superior a los demás se evidencia a partir de los poemas homéricos. Se trata de un dios que:

Luchó para obtener el poder celeste (contra su padre Crono y contra los Titanes y contra el terrible Tifón) y que luego ha sabido imponer un orden en el Olimpo. Allí sobre ese Olimpo (...) Zeus ha instalado su dominio estable, su hogar y su trono, el centro de control del cosmos (García Gual, 2003, p. 298).

En la obra, Dighero menciona entre las características de Júpiter que es superior a los demás, pues es el padre y rey de todos los dioses. Además, posee el rayo, con el cual venció a los Gigantes, se sienta en un solio de oro y marfil y lleva corona y cetro. Bajo sus pies se ubica un gigante, amenazado por el rayo, sometido, pero no muerto. El lemma de esta imagen es Premit, non dum perimit. Todas las características indicadas se corresponden con aquellas que ostentaba este dios en el mundo grecorromano y es fácil de comprender el paralelismo que se establece entre Zeus / Júpiter y el rey Carlos III por medio de elementos como el trono, la corona, la superioridad sobre los demás, etc.

Es interesante la presencia de un gigante sometido al dios junto al trono de Júpiter. Esto refiere al episodio de la Gigantomaquia: la lucha librada entre Zeus y los Gigantes. En la mitología grecolatina, Zeus, después de haberse confirmado como el rey de los dioses, debe todavía enfrentar enemigos formidables, como el monstruo Tifón o los Gigantes. Estos últimos, nacidos de la Tierra (Gea), fueron instigados por su madre para que atacaran al nuevo rey del universo, tal vez como venganza por la derrota de los Titanes. Después de varias batallas, Zeus y los demás dioses que lo acompañan logran vencer y matar a los Gigantes. ${ }^{3}$ En este caso, el gigante bajo los pies de Júpiter no ha muerto, pero sí está amenazado por el rayo que blande el dios. La muerte, traída por el gran dolor que sufre el rey a causa de la pérdida de su esposa,

\footnotetext{
${ }^{3}$ Este episodio no es referido por Hesíodo, pero sí por Apolodoro (2002, p. 16).
} 
está representada en el gigante: "El fantástico jayán, que atrevido/ sofocar a su Dueño había osado" (Dighero, 1763, p. 29) Sin embargo, cual Júpiter vencedor, el rey se sobrepone a su dolor y lo domina. Así se da sentido al lemma Premit non dum perimit (Oprime, [pero] todavía no destruye): con él se alude tanto a Júpiter en relación con el gigante representado en la pictura como al rey, cuyo espíritu ha sido oprimido por el sufrimiento, pero no derrotado.

\subsubsection{Su labor y ejercicio de manos: Vulcano (VIII)}

Este dios, el Hefesto griego, según Hesíodo (Teog. 927) era hijo de Hera sin trato amoroso (en otras versiones del mito era hijo de Zeus y Hera) y era el dios del fuego y los trabajos metalúrgicos, considerado el maestro artesano por excelencia (García Gual, 2003, p. 143). Dice su leyenda que, a causa de su fealdad, fue arrojado (por Hera o por Zeus) desde el Olimpo y cayó en la isla de Lemnos, lo que causó su característica cojera. En el jeroglífico se le representa como herrero, trabajando en una fragua con martillo y tenazas, y se le llama ejemplo de dignidad originada en el ejercicio de su virtuosa labor. El lemma es Iuvat indulgere labori, cita incompleta de la Eneida de Virgilio, pues son las palabras dichas por la Sibila a Eneas cuando este desea información para llegar al inframundo: "si te agrada arrostrar tan insensato empeño (...) et insano iuvat indulgere labori" (En.VI, v. 135). La Sibila busca advertir a Eneas de lo riesgoso de su empresa, pero en el jeroglífico el verso tiene la intención de alabar el empeño y la laboriosidad de la reina, los cuales la asemejan al dios Vulcano.

\subsubsection{Su recato, y silencio en la virtud: Saturno (XIV)}

Esta deidad, el Cronos griego, es el más joven de los hijos de Urano y Gea (Teog. 137). Este Titán se unió a Rea y devoró a sus hijos al nacer "para evitar ser destronado por alguno de sus hijos” (García Gual, 2003, p. 85), excepto a Zeus, quien posteriormente rescató a sus hermanos y venció a su padre en la Titanomaquia (Teog. 713-734). Por la similitud de su nombre griego (Krónos) con la palabra 'tiempo' (Xrónos) se le ha considerado como el Tiempo (Grimal, 1981, p. 121). En su pictura es representado como un viejo ceñudo mordiendo a un niño. El lemma es Edit quos edidit, se come a quienes engendró, en alusión 
a sus hijos. La relación con la difunta María Amalia radica en que, al igual que el Tiempo-Saturno se "come" los días como antes devoró a sus hijos, así la modestia de la reina en vida no pregonaba sus buenas obras, se las "tragaba". No obstante, igual que la descendencia de Cronos, con respecto a María Amalia estas buenas obras salieron a la luz y fueron conocidas por todos para gloria de la reina y, en opinión de Dighero (1763, p. 42), le allanaron el camino al cielo.

\subsection{Segunda estancia: Dioses terrestres y marinos}

La introducción a esta sección habla sobre "los afectos de la Nación en el sentimiento tan debido a la falta, que padecían con su muerte" (Dighero, 1763, p. 45). Por consiguiente, los emblemas de esta estancia expresan el llanto derramado a causa de ese dolor. Este llanto se acompaña de la música de flauta, instrumento asociado desde la época griega a los lamentos fúnebres (como la elegía).

\subsubsection{Pan (XVII)}

Se menciona aquí su estatus de divinidad pastoril y se describe su aspecto de mitad hombre mitad macho cabrío. Se narra también el episodio mitológico de su amor por la ninfa Siringa y cómo, al huir de él, ella fue transformada en cañas. Refiere Ovidio (Met I, vv. 707-710) que Pan, desolado por haberla perdido, fabricó una flauta de esas cañas, seducido por el dulce sonido que estas producían al pasar el viento entre ellas. En la versión de Dighero (1763), Pan ideó ese instrumento con tal de no perder por completo a su amada, o bien por "lamentar con voz más apacible su pérdida" (p. 46). El lemma, De illa et pro illa, alude a este lamento de Pan que es causado por la pérdida de la ninfa y expresado por medio del instrumento que de ella se originó. Del mismo modo, en las exequias de la reina el llanto de los vasallos españoles es motivado por la muerte de esta y acompañado del dulce sonido de la flauta.

\subsubsection{Ceres (XVIII)}

Asimilada a la griega Deméter, Ceres es hija de Rea y Crono, hermana de Zeus (Teog. 453). Es la diosa de las mieses y madre de Proserpina (Perséfone). Menciona Dighero (1763, p. 47) que, luego de ser 
raptada su hija por Plutón, Deméter encendió una antorcha en el monte Etna y buscaba a la muchacha desde el ocaso hasta el amanecer. De ahí el lemma Solis ab occasu solis quaerebat ad ortus, que es un verso de las Metamorfosis de Ovidio (V 445): la diosa buscaba a su hija desde donde el sol se pone hasta donde el sol nace. Esta era una frase formulaica que se utilizaba antiguamente en Grecia y Roma para indicar ya fuera un vasto territorio o bien todo el mundo conocido. En relación con las exequias reales, el lemma refiere al extenso territorio que sufre el luto por su muerte, en donde España es donde el sol sale (Oriente) y América donde el sol se pone (Occidente).

\subsubsection{Ino $(X X I V)$}

En la mitología griega, Ino era la hija de Cadmo, también conocida por el nombre de Leucótea (Grimal, 1981, p. 318; Martin, 1996, p. 254). Era esposa de Atamante, un rey de Beocia, a quien persuadió de que recogiera a Dioniso tras la muerte de su madre Sémele. No obstante, esto provocó la ira de Hera, la celosa esposa de Zeus. Por esto, la diosa envió a una Furia (Ovidio, 2008, Met. IV, vv. 495-99) para enloquecer a Ino y Atamante, a raíz de lo cual cada uno mató a un hijo propio. Dice Grimal (1981, p. 318) que Ino, desesperada, se arrojó al mar con el cadáver de su hijo. Neptuno, según Ovidio (2008, Met. IV, vv. 530-36), por mediación de Venus, de quien Ino era descendiente, la transformó en nereida y a su hijo en el dios Palemón; juntos sirven como guía a los marineros. Esta leyenda es la que se reproduce en el jeroglífico, con la imagen de Ino sumergiéndose en el mar y con el lemma Quod mortale fuit (el verso IV 540 de Ovidio), como referencia a que Neptuno le quitó a Ino lo que fue mortal y la transformó en divinidad. Del mismo modo que Ino no perdió su vida al lanzarse al mar, así es consuelo de los dolientes el que María Amalia con la muerte, "con mejoría notoria / para bañarse de gloria, / de lo mortal se desnuda" (Dighero, 1763, p. 59). 


\subsection{Tercera estancia: Dioses infernales}

Con estas divinidades se busca dar a los súbditos dolientes el mismo consuelo (ante el deceso de la reina) que sentían los paganos, quienes imaginaban que estas deidades podían conceder una mejor vida después de la muerte.

\subsubsection{La Noche (XXXV)}

Hija de Caos según la Teogonía de Hesíodo (124-25). En el emblema estaba representada con alas negras y un vestido oscuro sembrado de estrellas, sentada encima de un sepulcro. Según Dighero (1763), esta tumba pertenecía a "una muxer fuerte, cuyo esplendor no se apaga en la noche, como dixo el Sabio, de quien se toma el lemma: Non extinguitur lucerna eius" (p. 65). Esta cita se encuentra en la Biblia, en el libro de Proverbios atribuido a Salomón, posiblemente el sabio a quien se alude aquí. Sin embargo, en la Biblia estas palabras son pronunciadas por 'la madre del rey Lemuel', personaje de difícil identificación, equiparado a veces al mismo Salomón. El pasaje refiere a cómo debe ser la esposa idónea; la cita completa dice: "Cuida de que el negocio marche bien y de noche trabaja hasta tarde" (Prov. 31, 17-18) Sin embargo, en el contexto de las exequias de la reina, tanto la figura de la noche como la cita bíblica están adaptadas a los propósitos laudatorios: se figura a la reina como una luz (lucerna) tan poderosa que ni las tinieblas de la noche la pueden opacar.

\subsection{Cuarta estancia: Dioses honorarios}

Explica Dighero (1763) que se cuentan aquí divinidades "a quienes los gentiles veneraban por contribuir en su estimación al honor de los hombres, y aun de los dioses” (p. 66). Se advierte, con una cita del Eclesiastés $(11,30)$, sobre la imprudencia de la vanagloria en vida: Ante mortem ne laudes hominem, por cuanto solo el tiempo de la muerte es seguro y la fortuna puede cambiar. Se sigue con las alabanzas para la reina, las cuales vienen tras una santa vida y una buena muerte. 


\subsubsection{El Silencio $(X L)$}

Identificado con el dios Harpócrates, este era el nombre griego para el egipcio Horus en su infancia y se le representaba como un niño con el dedo sobre los labios. Por esto, los griegos (y luego los romanos) lo consideraban el dios del silencio y la discreción. El lemma era Dolori maximo y buscaba significar el hecho de que, ante el gran dolor como el causado por la muerte de María Amalia, la boca humana no bastaba para expresarlo, por lo que era preferible el silencio: "La boca no da en el punto: pues Dolor, ay! punto en boca" (Dighero, 1763, p. 69).

\section{Conclusiones}

El empleo de divinidades de la Antigüedad como vehículo para las alabanzas de la difunta reina María Amalia en las exequias celebradas en la ciudad de Santiago de los Caballeros de Guatemala resulta impresionante y, por lo mismo, efectivo como recurso retórico. Se puede afirmar que, con esta obra, se busca desarrollar lo que Rubial García (2007, p. 127) llama la función fundamental de la retórica: comunicar enseñanzas morales a partir de la descripción de virtudes. En este caso, las virtudes atribuidas a la difunta reina son transmitidas con la ayuda de divinidades de la tradición mitológica grecolatina.

Osorio (1989) indica, en referencia a las descripciones de arcos de triunfo y túmulos funerarios realizados en Nueva España (como el de la reina María Amalia de Sajonia), que estas estructuras fueron utilizadas como instrumento de propaganda fidei: "En los primeros a la par que se exaltaban las virtudes del príncipe, virrey u obispo, le pretendían inculcar lineamientos de gobierno; los segundos, al tiempo que alababan al muerto, manipulaban su vida para proponerla como ejemplo para los pósteros" (p. 176). Cabe señalar que, de acuerdo con Sánchez (2019), en las relaciones de exequias reales realizadas en Guatemala, "la reina no existe como individuo identificable, sino como personaje tipo con caracteres y atributos intercambiables" (p. 14). Por ello, la imagen que de la reina se presenta en la obra de Dighero es más bien una idealización general y no una descripción ajustada a la realidad del carácter y virtudes específicas de María Amalia de Sajonia. 
Con la escogencia del motivo metafórico central, el Panteón, la organización de las exequias reales relatadas por Dighero destaca la gran influencia de la tradición grecolatina para la civilización occidental presente durante el periodo colonial incluso, en una región periférica como Guatemala. En primer lugar, en la segunda elegía que antecede a la descripción de los emblemas funerarios, se menciona a las Musas como fuente de inspiración (Dighero, 1763, p. 24). Asimismo, la mayoría de las deidades utilizadas en los jeroglíficos provienen de la cultura grecolatina y las versiones de los mitos que las acompañan son, por lo general, las tradicionales en esa cultura. Empero, en ocasiones tanto las divinidades como como el lemma en lengua latina son utilizados fuera del contexto original con el fin de servir al motivo central de la obra: celebrar las exequias funerarias de la reina. Es el caso, por ejemplo, de la Noche que, inusualmente, es representada sobre un sepulcro, o la cita bíblica Non extinguitur lucerna eius, la cual en su contexto trata sobre la diligencia de la esposa modelo. Igualmente, la cita original de la Eneida adquiere aquí sentido laudatorio.

Con cada divinidad presentada, se va añadiendo un elemento que completa el tema propuesto para cada estancia y, con esto, se construye una imagen cada vez más acabada de la reina. Por ejemplo, en la estancia primera, cada divinidad introduce un atributo que poseía María Amalia y al final todas forman un cuadro completo de la virtud de la soberana. De igual manera, en la estancia segunda, se busca expresar el dolor causado por la muerte de la reina y el llanto de todos por ese luto. Así, el dios Pan alude a la música de flauta que acompaña en los orígenes de la literatura griega a la elegía (canto de duelo). Ceres, por su parte, simboliza los vastos territorios afectados por la pérdida de la reina e Ino aporta el consuelo de que María Amalia alcanzó una condición más favorable (como se dice popularmente, pasó a mejor vida).

Dighero afirma que en la primera estancia se colocaron las deidades más sobresalientes, con el propósito de que representaran las principales virtudes. Sin embargo, esto no es cierto en todos los casos: por un lado, se ve en esta estancia la presencia de divinidades no olímpicas, como Eolo y Astrea, y, por otro, dioses principales como Deméter, Neptuno o Diana no aparecen aquí sino en otras estancias. 
A pesar de emplear divinidades paganas, la obra no se aparta nunca de los valores y creencias cristianas. En ella se considera a los dioses de la Antigüedad como inválidos frente a Cristo; no obstante, se reconoce su valor como recurso retórico y símbolo de algunas virtudes:

Dissimulense por ahora tantos vicios, que torpemente veneró la gentilidad ciega en sus deidades: vaya en hora buena, y sea cierto, que en realidad lo que más conduxo al ánimo de los hombres a tanto delirio, fue alguna sobresaliente especie de virtud, conque resplandeciendo los grandes espíritus, deslumbraron fácilmente a los menos generosos (Dighero, 1763, p. 26).

En ocasiones, el autor incluso se burla de los paganos por aspectos que considera tonterías o ignorancia. Este es el caso de Pan (segunda estancia), pues al describirlo lo hace de la siguiente manera: "Su figura (invención ridícula!) era en la parte superior medio cuerpo de hombre, no mal parecido" (p. 45). Esta concepción negativa se ve también en Jano (estancia primera), divinidad importante en la cultura romana, cuya forma es considerada motivo de burla: "Dos caras encontradas tenía este Numen. Estupenda monstruosidad! (p. 43).

En conclusión, a pesar de su defensa de los valores cristianos y del desdén con que Dighero se refiere a los personajes paganos mencionados en el Pantheón real, el uso de personajes mitológicos, en su mayor parte provenientes de la cultura grecorromana, esta obra evidencia la importancia de esa tradición para la literatura occidental como recurso argumental y retórico. Por una parte, el conocimiento de la mitología clásica es necesario para la comprensión de los textos literarios e incluso muchas veces proporciona el asunto mismo del texto; por otra, la presencia del mito tiene, entre otras, una función de ornato (dentro de la elocutio) que contribuye a los fines retóricos de la obra.

\section{Referencias bibliográficas}

Allo Manero, M. A. y Esteban Llorente, J. F. (2004). El estudio de las exequias reales de la monarquía hispana: siglos XVI, XVII y XVIII. Artigrama, (19), 39-94. 
Álvarez Sánchez, A. (2016). Los catedráticos juristas de la Real Universidad de San Carlos de Guatemala (1678-1800). En M. Hidalgo Pego y R. Ríos Zúñiga (Coords.), Poderes y educación superior en el mundo hispánico: siglos xv al xx (pp. 139-166). México: IISUE-UNAM.

Apolodoro. (2002). Biblioteca mitológica. Madrid, España: Gredos.

Barchino, M. (2008). Mito y escritura en la obra de Carlos Fuentes: Diana o la cazadora solitaria. En J. Herrero Cecilia et al. (Eds.), Reescrituras de los mitos en la literatura: estudios de mitocrítica y de literatura comparada (pp. 89-100). Cuenca, España: Ediciones de la Universidad de Castilla-La Mancha.

Cristóbal, V. (1993). Maffeo Vegio y su Libro XIII de la Eneida. Cuadernos de Filología Clásica. Estudios latinos, ns. Madrid, España: Editorial Complutense.

Cristóbal, V. (2000). Mitología clásica en la literatura española: consideraciones generales y bibliografía. Cuadernos de Filología Clásica. Estudios Latinos, 18.

Dighero, J. A. (1763). El Pantheón real, fúnebre aparato a las exequias, que en la ciudad de Santiago de los Caballeros de Guatemala, se hicieron por el alma, y a la piadosa memoria de nuestra católica reina y señora, Doña María Amalia de Sajonia. Guatemala: Imprenta de Sebastián de Arévalo.

García Gual, C. (2003). Diccionario de mitos. Madrid, España: Editorial Siglo XXI.

Grimal, P. (1981). Diccionario de mitología griega y romana. Barcelona, España: Paidós.

Henkel, A. y Schöne, A. (1967). Emblemata. Handbuch zur Sinnbildung des XVI. und XVII. Jahrhunderts. Stuttgart / Weimar, Alemania: J. B. Metzler Verlag.

Hesíodo. (1997). Obras y fragmentos. Madrid, España: Gredos.

Martin, R. (1996). Diccionario Espasa Mitología griega y romana. Madrid, España: Editorial Espasa Calpe S. A.

Osorio Romero, I. (1989). El género emblemático de Nueva España. En I. Osorio Romero, Conquistar el eco. Las paradojas de la conciencia criolla (pp. 173-188). México: Universidad Nacional Autónoma de México. 
Ovidio. (2008). Metamorfosis. Traducción, introducción y notas de J. Carlos Fernández Corte y J. Cantó Llorca. Madrid, España: Gredos.

Rubial García, A. (2007). La muerte como discurso retórico en algunos textos novohispanos. Anuario de Historia, 1, 125-142). Universidad Nacional Autónoma de México. Facultad de Filosofía y Letras. Sánchez Mora, A. (2016). Las relaciones de fiestas impresas del reino de Guatemala, siglos XVII a XIX. Anales de la Academia de Geografía e Historia de Guatemala, XCI.

Sánchez Mora, A. (2019). Las relaciones fúnebres de reinas del siglo XVIII en el antiguo reino de Guatemala: acercamiento a sus programas emblemáticos. En R. Cubillo Paniagua y R. Campos López (Eds.), Estudios actuales de literatura comparada: teorías de la literatura y diálogos interdisciplinarios (Vol. 2). San José, Costa Rica: Vicerrectoría de Investigación, Universidad de Costa Rica, pp. 295-314.

Skinfill Nogal, B. (2002). Los caminos de la emblemática novohispana: una aproximación bibliográfica. En B. Skinfill Nogal y E. Gómez Bravo (Eds.), Las dimensiones del arte emblemático. Zamora, Michoacán, México: El Colegio de Michoacán, pp. 45-72.

Ureña Bracero, J, (2001). Alciato y el poder de la palabra: poesía, retórica y jeroglíficos. Anuario de Estudios Filológicos, XXIV, 437-451.

Virgilio. (2010). Eneida. Madrid, España: Gredos. 